\title{
Analisis Pemilihan Calon Penerima Beasiswa Daerah dengan Metode Analytical Hierarchy Process dan Profile Matching (Studi Kasus: Universitas Darwan Ali, Sampit, Kalimantan Tengah)
}

\author{
${ }^{1}$ Lukman Bachtiar, ${ }^{2}$ Kusrini \\ Magister Teknik Informatika Universitas AMIKOM Yogyakarta Indonesia \\ e-mail: ${ }^{1}$ lukman.bachtiar@gmail.com, ${ }^{2}$ kusrini@amikom.ac.id
}

\begin{abstract}
Abstrak
Sistem pendukung keputusan (SPK) dengan metode Analytical Hierarchy Process (AHP) menguji nilai Consistency Ratio (CR) menentukan kelayakan tatanan perbandingan derajat kepentingan tiap-tiap kriteria. Pemrosesan metode AHP ini sampai menghasilkan nilai Prioritas tiap-tiap persyaratan. Jika nilai CR telah layak maka dapat dilanjutkan ke tahap pencarian solusi dengan metode Profile Matching (PM) untuk menyeleksi calon penerima beasiswa. Nilai Prioritas tiaptiap persyaratan dari metode AHP kemudian dikelompokkan oleh metode PM ke dalam grup Core Factor dan grup Secondary Factor berdasarkan urutan descending nilai Prioritas. SPK ini dipakai oleh bagian Kemahasiswaan untuk menyeleksi para mahasiswa untuk diusulkan ke Bagian Kesra kabupaten dalam program Beasiswa Gerbang Mentaya. Keluaran pertama SPK berupa rincian perhitungan AHP mendapatkan nilai CR dengan konfirmasi apakah sudah dapat melakukan pencarian solusi ataukah masih harus menata kembali tatanan nilainilai perbandingan derajat kepentingan tiap-tiap persyaratan. Keluaran kedua memuat rincian pemrosesan PM menilai persyaratan para mahasiswa. Keluaran terakhir berupa daftar para mahasiswa yang benar-benar layak diusulkan menerima beasiswa berdasarkan seleksi penilaian, seleksi status warga tetap kabupaten, dan status tidak sedang menerima beasiswa dari pihak lain, yang kemudian diusulkan oleh bagian Kemahasiswaan kepada Bagian Kesra Kabupaten Kotawaringin Timur.
\end{abstract}

Kata kunci : penerima, beasiswa, daerah, pendukung, keputusan, status, penduduk.

1. Pendahuluan

Berdasarkan Pengumuman Bupati Kotawaringin Timur Nomor 422.5/1642/Bag.Kesra tentang Penjaringan Calon Penerima Beasiswa Gerbang Mentaya dari Pemerintah Kabupaten Kotawaringin Timur Tahun 2018, para pelajar dan mahasiswa mendapat kesempatan untuk mengikuti perekrutan beasiswa ini dengan beberapa kategori calon penerima beasiswa, yaitu meliputi a) Calon Penerima Beasiswa Mahasiswa Kurang Mampu, b) Calon Penerima Beasiswa Tahap Akhir, c) Calon Penerima Beasiswa Pelajar dan Mahasiswa Berprestasi Akademik dan Non Akademik, dan d) Calon Penerima Beasiswa Usia Sekolah.

Pada umumnya Beasiswa Gerbang Mentaya ini memiliki beberapa persyaratan yang meliputi: a) Calon penerima beasiswa merupakan warga Kabupaten Kotawaringin Timur. Hal ini dapat dibuktikan dengan melampirkan Kartu Keluarga ataupun Kartu Tanda Penduduk milik pelajar / mahasiswa ataupun 
orangtua / walinya, b) Memiliki Kartu Raskin ataupun Kartu Perlindungan Sosial (KPS) ataupun Surat Keterangan Tidak Mampu (SKTM), c) Tidak sedang menerima beasiswa dari pihak lain, d) Khusus mahasiswa, memiliki Indeks Prestasi minimal 2.5, e) Memiliki prestasi dengan bukti piagam ataupun sertifikat ataupun surat keterangan yang lain, dan f) Melengkapi persyaratan administrasi pengajuan permohonan beasiswa.

Suatu kekurangan yang ditemukan oleh peneliti dalam perekrutan calon penerima beasiswa ini adalah belum diterapkan metode-metode logika dalam sistem pendukung keputusan pada pengolahan penilaian calon penerima beasiswa itu. Kegiatan tim penilai hanya memeriksa kelengkapan berkas pendaftaran yang diberikan oleh para pendaftar calon penerima beasiswa. Situasi ini disebabkan oleh beberapa hal yaitu: a) Terdapat empat pilihan jenis beasiswa yang disediakan oleh Bupati Kotawaringin Timur, b) Tiap-tiap pilihan jenis beasiswa itu memiliki persyaratan yang berbeda maupun persyaratan yang mirip, dan c) Untuk menentukan pemilihan calon penerima yang lolos mendapatkan beasiswa hanya berdasarkan kelengkapan berkas pendaftaran.

Permasalahan dalam penelitian ini dapat dirumuskan sebagai berikut

a. Bagaimanakah cara menggabungkan metode Analytical Hierarchy Process dan metode Profile Matching dalam sistem pendukung keputusan di Universitas Darwan Ali untuk memilih para mahasiswa yang dapat diusulkan menerima beasiswa Gerbang Mentaya?

b. Berapa tingkat akurasi dari hasil perhitungan keluaran program jika dibandingkan dengan perhitungan manual?

Tujuan dari penelitian ini adalah untuk membuat suatu analisis pada sistem pendukung keputusan di Universitas Darwan Ali untuk memilih mahasiswa yang layak diusulkan kepada Kantor Kesra Kabupaten Kotawaringin Timur untuk mendapat beasiswa Gerbang Mentaya. Peneliti memakai metode Analytical Hierarchy Process (AHP) untuk menganalisis kelayakan perbandingan derajat kepentingan tiap-tiap persyaratan dan dilanjutkan dengan pembuatan keputusan dengan metode Profile Matching (PM) untuk perekrutan mahasiswa yang diusulkan menerima beasiswa itu. Hasil dari penelitian ini adalah berupa daftar para mahasiswa yang layak diusulkan kepada Kantor Kesra Kabupaten Kotawaringin Timur untuk dapat menerima beasiswa Gerbang Mentaya. Alasan peneliti memakai metode AHP adalah untuk menganalisis kelayakan perbandingan derajat kepentingan tiap-tiap persyaratan antarkriteria, karena metode ini mengizinkan menata kembali skore-skore derajat kepentingan yang diuji sampai mendapatkan nilai Consistency Ratio (CR) yang layak, sebelum masuk ke tahap pencarian solusi. Selama nilai CR belum layak (lebih besar dari 0.1) maka skore-skore derajat kepentingan yang diuji itu dapat diperbaiki kembali. Setelah mendapatkan nilai CR layak (kurang dari 0.1), maka nilai-nilai prioritas yang telah diperoleh dengan metode AHP dapat diacu sebagai nilai Core Factor (CF) dan nilai Secondary Factor (SF) di metode PM untuk mencari solusi. Alasan peneliti memakai metode PM dalam pencarian solusi adalah karena setiap 
persyaratan pada suatu permasalahan dapat dikelompokkan ke dalam grup $\mathrm{CF}$ sebagai kelompok persyaratan primer dan ke dalam grup $S F$ sebagai kelompok persyaratan sekunder.

Tujuan dari penelitian ini dapat dicapai oleh peneliti dengan memakai beberapa cara di bawah ini:

a. Melakukan analisis perhitungan dengan formula Microsoft Excel untuk menentukan penyeleksian para mahasiswa Universitas Darwan Ali Sampit dengan metode AHP dan metode PM untuk dapat diusulkan menerima beasiswa Gerbang Mentaya.

b. Membuat keluaran dari hasil analisis berupa informasi daftar mahasiswa yang benar-benar layak untuk diusulkan kepada Kantor Kesra Kabupaten Kotawaringin Timur untuk menerima beasiswa Gerbang Mentaya.

2. Kajian Pustaka

\subsection{Tinjauan Pustaka}

Suatu ciri khas dari penelitian Tesis saat ini adalah memakai dua buah metode, yaitu metode AHP dipakai untuk menganalisis kelayakan nilai CR, dan metode PM dipakai untuk mencari solusi dari permasalahan. Proses perhitungan dengan metode AHP dimulai dengan menganalisis perbandingan derajat kepentingan tiap-tiap persyaratan sampai mendapatkan nilai CR yang layak sesuai ketentuan AHP. Metode PM memroses pencarian solusi dengan memakai nilai Prioritas setiap persyaratan yang telah diperoleh dengan pemrosesan sebelumnya dengan metode AHP. Nilai Prioritas ini dipakai oleh metode PM untuk mengelompokkan persyaratan permasalahan beasiswa ini masuk ke dalam grup CF dan grup SF. Di bagian akhir pemrosesan metode PM masih ditambah dengan satu langkah eliminasi dengan suatu operasi logika untuk menemukan sebuah solusi final jika dihadapkan dengan beberapa subkeputusan.

Penelitian Tesis saat ini dilakukan berdasarkan beberapa rujukan penelitian terdahulu, yaitu:

a. Metode AHP dipakai untuk membuat keputusan perekrutan karyawan baru untuk mempermudah kegiatan penyeleksian para pelamar dalam penelitian Sasongko dan rekan (2017). Penelitian Sasongko dan rekan ini hanya menerapkan metode AHP dan langsung menemukan solusi final, sedangkan penelitian pada Tesis ini memiliki ciri khas yang telah dijelaskan pada alinea pertama sub Tinjauan Pustaka ini.

b. Puspitasari dan rekan (2017) memiliki penelitian dengan hasil suatu sistem pendukung keputusan dengan metode AHP untuk memecahkan permasalahan pemberian beasiswa pada suatu sekolah di Jawa Timur. Penelitian Puspitasari dan rekan ini tidak memiliki ciri khas dari penelitian Tesis saat ini yang telah dijelaskan pada alinea pertama sub Tinjauan Pustaka ini. 
c. Sistem pendukung keputusan dengan metode PM untuk penempatan jabatan telah diteliti oleh Sahureka (2017). Hal pembeda dengan penelitian Tesis saat ini adalah penelitian Sahureka hanya menerapkan metode PM dan tidak memiliki ciri khas dari penelitian Tesis saat ini yang telah dijelaskan pada alinea pertama sub Tinjauan Pustaka ini.

d. Pemakaian dua buah metode dalam sebuah penelitian telah dilakukan oleh Astradanta dan rekan (2016) dengan cara perbandingan multikriteria diuji dengan metode AHP dan pencarian solusi memakai metode Simple Additive Weighting (SAW). Penelitian Astradanta dan rekan ini memakai dua buah metode untuk mencari solusi sesuai alur algoritma dua metode itu, dan tidak memiliki ciri khas dari penelitian Tesis saat ini yang telah dijelaskan pada alinea pertama sub Tinjauan Pustaka ini.

e. Pemakaian metode PM dan metode AHP pada penelitian Moedjiono dan rekan (2016) dapat menganalisis kelayakan pemilihan karyawan, namun penelitian Moedjiono dan rekan ini tidak dihadapkan dengan munculnya beberapa subsolusi dan tidak memiliki ciri khas dari penelitian Tesis saat ini yang telah dijelaskan pada alinea pertama sub Tinjauan Pustaka ini.

f. Metode PM pada penelitian Khotijah dan rekan (2017) dapat memberikan rekomendasi berupa informasi beberapa sekolah yang dapat dipilih orangtua para calon siswa Taman Kanak-kanak. Khotijah dkk (2017) hanya memakai metode PM pada penelitiannya dan tidak memiliki ciri khas dari penelitian Tesis saat ini yang telah dijelaskan pada alinea pertama sub Tinjauan Pustaka ini.

g. Implementasi metode logika PM telah dipakai oleh Sambani dan rekan (2016) untuk menyeleksi kelayakan dalam perekrutan calon pengajar. Penelitian Tesis saat ini sama seperti penelitian Sambani dkk, yaitu menggunakan metode PM untuk pencarian solusi. Namun penelitian Sambani dan rekan tidak memiliki ciri khas dari penelitian Tesis saat ini yang telah dijelaskan pada alinea pertama sub Tinjauan Pustaka ini.

\subsection{Sistem}

Definisi tentang sistem dapat dibuat berdasarkan dua hal penekanan, yaitu: a) Kelompok yang memberi penekanan kepada hal komponen, mendefinisikan sistem sebagai suatu seri dari subsistem-subsistem yang saling berhubungan, bekerja sama di dalam suatu kerangka kerja dan tahapan yang terpadu untuk menyelesaikan dan mencapai sasaran yang telah ditetapkan sebelumnya [1]. Jogianto (1993) berpendapat bahwa komponen sistem adalah berupa subsistem, b) Sedangkan kelompok yang memberi penekanan kepada hal prosedur, memberi definisi tentang sistem sebagai suatu jaringan kerja yang saling berhubungan, berkumpul bersama-sama untuk melakukan suatu kegiatan atau untuk menyelesaikan suatu sasaran yang tertentu [1]. 


\subsection{Sistem Pendukung Keputusan}

Beberapa penulis memberikan definisi mengenai sistem pendukung keputusan, antara lain sebagai: a) merupakan sistem berbasis komputer interaktif yang membantu para pengambil keputusan untuk menggunakan data dan berbagai model untuk memecahkan masalah yang tidak terstruktur [2], dan b) merupakan sistem berbasis komputer yang ditujukan untuk membantu pengambil keputusan dengan memanfaatkan data dan model untuk mengidentifikasi, memecahkan masalah dan membuat keputusan [3]. Wahid (2005) menyebutkan bahwa sistem pendukung keputusan biasa disebut dengan istilah Decision Support System.

Sistem penunjang keputusan adalah sistem interaktif berbantuan komputer yang mendukung pemakai dalam kemudahan akses terhadap data dan model keputusan dalam upaya membantu proses pengambilan keputusan yang efektif dalam memecahkan masalah yang bersifat semi terstruktur dan tidak terstruktur, karena itu harus mampu a) Ditambah atau dikembangkan, b) Mendukung analisis data dan model desisi, c) Berorientasi pada masa yang akan datang, dan d) Digunakan dalam waktu yang tidak terjadwal [4]

Terdapat tiga komponen besar yang saling berhubungan di dalam suatu sistem pendukung keputusan, seperti yang ditunjukkan melalui Gambar 1.

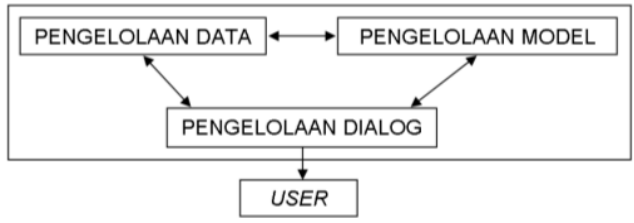

Gambar 1. Komponen Sistem Pendukung Keputusan [5]

Hubungan dari komponen-komponen pada gambar 1 dapat dijelaskan sebagai berikut: a) Pengelolaan Data (Database Management) merupakan subsistem data yang terorganisasi dalam suatu basis data. Data yang merupakan suatu sistem pendukung keputusan dapat berasal dari luar maupun dalam lingkungan. Untuk keperluan sistem pendukung keputusan diperlukan data yang relevan dengan permasalahan yang hendak dipecahkan melalui simulasi, b) Pengelolaan Model (Model Base) merupakan suatu model yang merepresentasikan permasalahan ke dalam format kuantitatif (model matematika sebagai contohnya) sebagai dasar simulasi atau pengambilan keputusan, termasuk didalamnya tujuan dari permasalahan (obyektif), komponen-komponen terkait, batasan-batasan yang ada (constraints), dan hal-hal terkait lainnya. Model Base memungkinkan pengambil keputusan menganalisa secara utuh dengan mengembangkan dan membandingkan solusi alternatif, c) Pengelolaan Dialog (User Interface) merupakan penggabungan antara dua komponen sebelumnya yaitu Database Management dan Model Base yang disatukan dalam komponen ketiga (user interface), setelah sebelumnya dipresentasikan dalam bentuk model yang dimengerti komputer. User interface menampilkan keluaran sistem bagi pemakai dan menerima masukan dari pemakai ke dalam sistem pendukung 
keputusan [5]. Kusrini (2007) berpendapat bahwa komponen User Interface sering disebut sebagai Subsistem Dialog [5].

Beberapa keuntungan yang dapat diambil jika suatu sistem pendukung keputusan dapat diimplementasikan adalah: a) Mampu mendukung pencarian solusi dari berbagai permasalahan yang kompleks, b) Dapat merespon dengan cepat pada situasi yang tidak diharapkan dalam kondisi yang berubah-ubah, c) Mampu untuk menerapkan berbagai strategi yang berbeda pada konfigurasi berbeda secara cepat dan tepat, d) Meningkatkan kontrol manajemen dan kinerja, e) Menghemat biaya dan sumber daya manusia, f) Menghemat waktu karena keputusan dapat diambil dengan cepat, dan g) Meningkatkan efektivitas manajerial, menjadikan manajer dapat bekerja lebih singkat dan dengan sedikit usaha. [6]

\subsection{Analytical Hierarchy Process}

Salah satu model yang dapat digunakan sebagai proses pengambilan keputusan adalah dengan menggunakan Proses Hierarki Analitik atau yang dikenal dengan istilah Analytical Hierarchy Process, yang dikembangkan oleh Dr. Thomas L. Saaty dari Wharton School of Business pada tahun 1970-an. Dengan menggunakan Analytical Hierarchy Process suatu persoalan yang akan dipecahkan dalam suatu kerangka berpikir yang terorganisir, sehingga memungkinkan dapat diekspresikan untuk mengambil keputusan yang efektif atas persoalan tersebut. Persoalan yang kompleks dapat disederhanakan dan dipercepat proses pengambilan keputusannya. [7]

Prinsip kerja Analytical Hierarchy Process terdiri dari: [4]

a. Penyusunan Hierarki, memiliki arti bahwa persoalan yang akan diselesaikan diuraikan menjadi unsur-unsurnya, yaitu kriteria dan alternatif, kemudian disusun menjadi struktur hirarki.

b. Kriteria dan Alternatif dinilai melalui perbandingan berpasangan, yang menurut Saaty (1983) menyebutkan bahwa untuk berbagai persoalan, skala 1 sampai 9 adalah skala terbaik dalam mengekspresikan pendapat. Nilai dan definisi pendapat kualitatif dari skala perbandingan Saaty dapat dilihat pada Tabel 1.

Tabel 1. Skala Penilaian Perbandingan Berpasangan (Saati, 2008) [4]

\begin{tabular}{lll}
\hline $\begin{array}{l}\text { Tingkat } \\
\text { Kepentingan }\end{array}$ & Definisi & Keterangan \\
\hline 1 & Sama penting & $\begin{array}{l}\text { Kedua elemen mempunyai pengaruh yang } \\
\text { sama }\end{array}$ \\
\hline 3 & Sedikit lebih penting & $\begin{array}{l}\text { Pengalaman dan penilaian sangat memihak } \\
\text { satu elemen dibandingkan dengan } \\
\text { pasangannya }\end{array}$ \\
\hline 5 & Lebih penting & $\begin{array}{l}\text { Satu elemen sangat disukai dan secara } \\
\text { praktis dominasinya sangat nyata, } \\
\text { dibandingkan dengan elemen pasangannya }\end{array}$ \\
\hline
\end{tabular}


Tabel 1. Lanjutan

\begin{tabular}{lll}
\hline $\begin{array}{l}\text { Tingkat } \\
\text { Kepentingan }\end{array}$ & Definisi & Keterangan \\
\hline 7 & Sangat penting & $\begin{array}{l}\text { Satu elemen terbukti sangat disukai dan } \\
\text { secara praktis dominasinya sangat nyata, } \\
\text { dibandingkan dengan elemen pasangannya }\end{array}$ \\
\hline 9 & Mutlak lebih penting & $\begin{array}{l}\text { Satu elemen mutlak lebih disukai } \\
\text { dibandingkan dengan pasangannya, pada } \\
\text { tingkat keyakinan tertinggi }\end{array}$ \\
\hline $2,4,6,8$ & $\begin{array}{l}\text { Nilai tengah-tengah di } \\
\text { antara dua pendapat } \\
\text { yang berdampingan }\end{array}$ & Nilai-nilai ini diperlukan suatu kompromi \\
\hline
\end{tabular}

c. Penentuan Prioritas, dapat dilakukan melalui perbandingan berpasangan (pairwise comparisons) untuk setiap kriteria dan alternatif. Nilai-nilai perbandingan relatif kemudian diolah untuk menentukan peringkat relatif dari seluruh alternatif. Baik kriteria kualitatif maupun kriteria kuantitatif dapat dibandingkan sesuai dengan judgement yang telah ditentukan untuk menghasilkan bobot dan prioritas. Bobot atau prioritas dihitung dengan manipulasi matrik atau melalui penyelesaian persamaan matematik.

d. Konsistensi Logis, dilakukan dengan cara mengelompokkan semua elemen secara logis dan diperingkatkan secara konsisten sesuai dengan suatu kriteria yang logis.

Pengukuran Consistency Index (CI) dimaksudkan untuk mengetahui konsistensi jawaban yang akan berpengaruh pada kesahihan hasil. Perhitungan CI dapat dihitung dengan Persamaan 1. [7]

$$
\mathrm{CI}=\frac{\lambda_{\text {max }}-\mathrm{n}}{\mathrm{n}-1}
$$

Untuk mengetahui apakah CI dengan besaran tertentu cukup baik atau tidak, perlu diketahui rasio yang dianggap baik, yaitu apabila nilai Consistency Ratio $(\mathrm{CR}) \leq 0,1$. Nilai CR dapat dihitung dengan Persamaan 2. [7]

$$
\mathrm{CR}=\mathrm{CI} / \mathrm{RI}
$$

CR merupakan parameter yang digunakan untuk memeriksa apakah perbandingan berpasangan telah dilakukan dengan konsekuen atau tidak. Nilai Random Indeks (RI) merupakan nilai random indeks yang dikeluarkan oleh Oarkridge Laboratory seperti pada data pada Tabel 2.

Tabel 2. Skala Nilai Random Indeks Oarkridge Laboratory [7]

\begin{tabular}{ll}
\hline Ukuran Matrik (n) & Nilai Index Random (IR) \\
\hline 1 & 0 \\
\hline 2 & 0 \\
\hline 3 & 0,58 \\
\hline
\end{tabular}


Tabel 2. Lanjutan

\begin{tabular}{ll}
\hline Ukuran Matrik (n) & Nilai Index Random (IR) \\
\hline 4 & 0,9 \\
\hline 5 & 1,12 \\
\hline 6 & 1,24 \\
\hline 7 & 1,32 \\
\hline 8 & 1,41 \\
\hline 9 & 1,45 \\
\hline 10 & 1,49 \\
\hline 11 & 1,51 \\
\hline 12 & 1,48 \\
\hline 14 & 1,56 \\
\hline 15 & 1,57 \\
\hline
\end{tabular}

\subsection{Profile Matching}

Metode Profile Matching atau Pencocokan Profil adalah metode yang sering digunakan sebagai mekanisme dalam pengambilan keputusan dengan mengasumsikan bahwa terdapat tingkat variable predictor yang ideal yang harus dipenuhi oleh subyek yang diteliti, bukannya tingkat minimal yang harus dipenuhi atau dilewati. Dalam proses profile matching secara garis besar merupakan proses membandingkan antara setiap kriteria setiap penilaian dalam sebuah proposal usulan penelitian yang diajukan sehingga diketahui perbedaan skornya (disebut juga gap), semakin kecil gap yang dihasilkan maka bobot nilainya semakin besar yang berarti memiliki peluang lebih besar untuk prioritas kelayakan/kelulusan [5]. Nilai gap ditunjukkan pada Gambar 2.

\begin{tabular}{|l|l|l|l|}
\hline No. & Selisih Gap & Bobot Nilai & Keterangan \\
\hline 1. & 0 & 5 & Kompetensi Sesuai dengan yang dibutuhkan \\
\hline 2. & 1 & 4.5 & Kompetensi Individu Kelebihan 1 tingkat \\
\hline 3. & -1 & 4 & Kompetensi Individu Kurang 1 tingkat \\
\hline 4. & 2 & 3.5 & Kompetensi Individu Kelebihan 2 tingkat \\
\hline 5. & -2 & 3 & Kompetensi Individu Kurang 2 tingkat \\
\hline 6. & 3 & 2.5 & Kompetensi Individu Kelebihan 3 tingkat \\
\hline 7. & -3 & 2 & Kompetensi Individu Kurang 3 tingkat \\
\hline 8. & 4 & 1.5 & Kompetensi Individu Kelebihan 4 tingkat \\
\hline 9. & -4 & 1 & Kompetensi Individu Kurang 4 tingkat \\
\hline
\end{tabular}

Gambar 2. Bobot Nilai Gap [8]

Langkah-langkah dalam penyelesaian perhitungan dengan menggunakan metode Profile Matching: [8]

a. Menentukan aspek-aspek penilaian. 
b. Membuat pemetaan gap kompetisi.

c. Memberi pembobotan gap kompetisi.

d. Menghitung dan mengelompokkan Core Factor dan Secondary Factor.

Nilai Core Factor dapat dihitung dengan Persamaan 3.

$$
\mathrm{NCF}=\boldsymbol{\Sigma} \mathrm{NC}(\text { aspek }) / \Sigma \mathrm{IC}
$$

Yang mana: $\mathrm{NCF}=$ Nilai rata-rata core factor, $\Sigma \mathrm{NC}($ aspek $)=$ Jumlah total nilai core factor, dan $\mathrm{IIC}=$ Jumlah item core factor. [9]

Nilai Secondary Factor dapat dihitung dengan Persamaan 4.

$$
\mathrm{NSF}=\boldsymbol{\Sigma} \mathrm{NS}(\text { aspek }) / \Sigma \mathrm{IS}
$$

Yang mana: NSF = Nilai rata-rata secondary factor, $\Sigma \mathrm{NS}$ (aspek) $=$ jumlah total nilai secondary factor, dan $\Sigma$ IS = Jumlah item secondary factor. [9]

e. Perhitungan nilai total.

Nilai total untuk tiap-tiap kandidat dapat dihitung dengan Persamaan 5.

$$
(\mathrm{x}) \% \mathrm{NCF}(\text { aspek })+(\mathrm{x}) \% \mathrm{NSF}(\text { aspek })=\mathrm{N}(\text { aspek })
$$

Yang mana: $\mathrm{NCF}($ aspek) = nilai rata-rata core factor (aspek), NSF $($ aspek $)=$ nilai rata-rata secondary factor $($ aspek $), \mathrm{N}($ aspek $)=$ nilai aspek (aspek), dan (x)\% = input nilai persen. [10]

f. Perhitungan penentuan ranking mengacu pada hasil perhitungan

Penentuan ranking dapat dihitung dengan Persamaan 6.

$$
\Sigma(\mathrm{x}) \% \mathrm{Nk}
$$

Yang mana: $\mathrm{Nk}=$ nilai kriteria, dan $(\mathrm{x}) \%=$ input nilai persen. [11]

\subsection{Pengertian Beasiswa}

Beasiswa adalah pemberian berupa bantuan keuangan yang diberikan kepada perorangan yang bertujuan untuk digunakan demi keberlangsungan pendidikan yang ditempuh [12]. Dalam Kamus Besar Bahasa Indonesia (KBBI), beasiswa adalah tunjangan yang diberikan kepada pelajar atau mahasiswa sebagai bantuan biaya belajar. Beasiswa diartikan sebagai bentuk penghargaan yang diberikan kepada individu agar dapat melanjutkan pendidikan ke jenjang yang lebih tinggi [13]. Penghargaan itu dapat berupa akses tertentu pada suatu institusi atau penghargaan berupa bantuan keuangan. Undang-undang Nomor 20 Tahun 2003 tentang Sistem Pendidikan Nasional, Bab V pasal 12 (1.c), menyebutkan bahwa setiap peserta didik pada setiap satuan pendidikan berhak mendapatkan beasiswa bagi yang berprestasi yang orang tuanya tidak mampu membiayai pendidikannya. Pasal 12 (1.d), menyebutkan bahwa setiap peserta didik 
pada setiap satuan pendidikan berhak mendapatkan biaya pendidikan bagi mereka yang orang tuanya tidak mampu membiayai pendidikannya [13].

\subsection{Pengertian Kartu Perlindungan Sosial}

Kartu Perlindungan Sosial (KPS) adalah kartu yang diterbitkan oleh Pemerintah sebagai penanda rumah tangga miskin. KPS dirancang sebagai penanda universal bagi rumah tangga sasaran (RTS) untuk mengakses program perlindungan. memuat informasi: Nama Kepala Rumah Tangga, Nama Pasangan Kepala Rumah Tangga, Nama Anggota Rumah Tangga Lain, Alamat Rumah Tangga, Nomor Kartu Keluarga, dilengkapi dengan kode batang (barcode) beserta nomor identitas KPS yang unik. Kartu Perlindungan Sosial berguna untuk mendapatkan program subsidi beras (RASKIN), Bantuan Siswa Miskin (BSM), Bantuan Langsung Tunai (BLT), dan bantuan-bantuan yang lain [14].

3. Metodologi Penelitian

Langkah-langkah penelitian yang dilakukan peneliti mengikuti alur seperti yang ditunjukkan pada Gambar 3 di bawah.

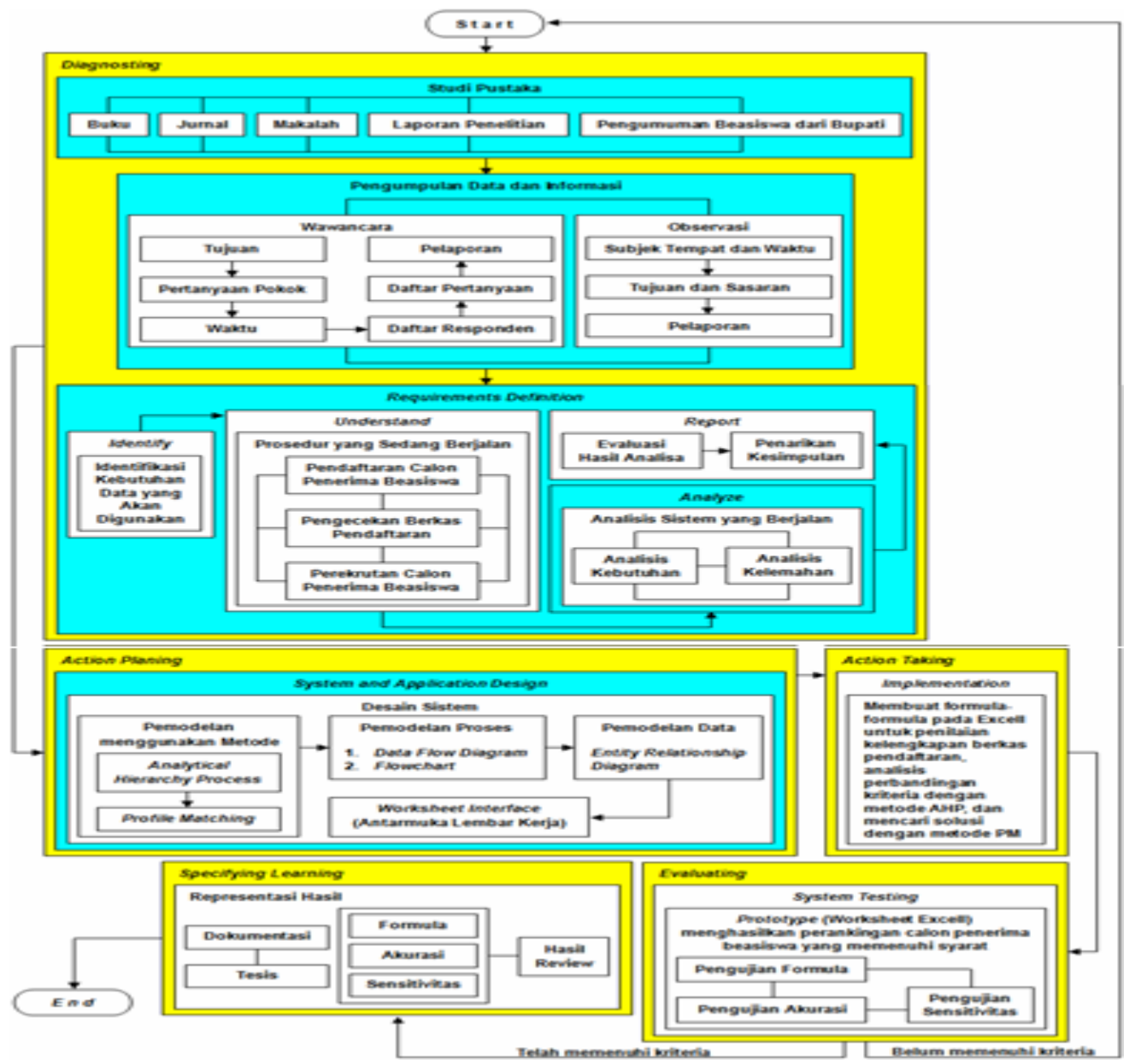

Gambar 3. Alur Penelitian 
Tahap studi pustaka dilakukan dengan tujuan untuk memperoleh pengertian secara teori mengenai sistem, sistem pendukung keputusan, dan alur algoritma dari metode-metode logika dalam sistem pendukung keputusan yang dipakai dalam penelitian ini.

Pada tahap pengumpulan data dan informasi peneliti dapat menemukan informasi mengenai kendala penanganan perekrutan calon penerima beasiswa dan mengetahui aturan maupun kriteria yang ditetapkan dalam perekrutan calon penerima beasiswa Gerbang Mentaya ini. Kriteria-kriteria yang menjadi bahan pertimbangan untuk pemberian beasiswa seperti yang diperinci pada Tabel 3.

Tabel 3. Kriteria Pemberian Beasiswa Gerbang Mentaya

\begin{tabular}{lll}
\hline Nama Kriteria & Keterangan & Bobot \\
\hline P1 & Warga Kabupaten Kotawaringin Timur & $15 \%$ \\
\hline P2 & Memiliki Kartu Raskin / KPS / SKTM & $20 \%$ \\
\hline P3 & Kelengkapan persyaratan administrasi & $10 \%$ \\
\hline P4 & Untuk mahasiswa, memiliki IP minimal 2.50 & $20 \%$ \\
\hline P5 & Memiliki prestasi non-akademik / lomba-lomba & $20 \%$ \\
\hline P6 & Tidak sedang menerima beasiswa dari pihak lain & $15 \%$ \\
\hline
\end{tabular}

Dari hasil observasi dan wawancara ini peneliti memahami bahwa kriteriakriteria yang ditulis pada Tabel 3 dapat dijadikan sebagai kriteria-kriteria yang akan diolah dengan metode-metode sistem pendukung keputusan yang dipakai dalam penelitian ini, sehingga nanti di dalam alur perhitungan pengambilan keputusan melalui metode-metode itu harus mengacu ke data pada Tabel 3 untuk pengolahan data penjaringan nama-nama mahasiswa yang dapat diusulkan untuk menerima beasiswa Gerbang Mentaya.

Data pada Tabel 4 merupakan data nilai untuk prestasi lomba-lomba yang diperoleh peneliti dari Kantor Dinas Pendidikan Kabupaten Kotawaringin Timur. Data ini terkait dengan kriteria kelima yang tertulis pada Tabel 3 sebelumnya.

Tabel 4. Ketentuan Nilai Piagam Penghargaan

\begin{tabular}{|c|c|c|c|c|}
\hline \multirow{2}{*}{ Kode } & \multirow{2}{*}{$\begin{array}{l}\text { Tingkat } \\
\text { Event }\end{array}$} & \multirow{2}{*}{$\begin{array}{l}\text { Tingkat } \\
\text { Juara }\end{array}$} & \multicolumn{2}{|l|}{ Nilai } \\
\hline & & & Beregu & Perorangan \\
\hline PP1 & \multirow{3}{*}{ Kabupaten } & III & 7,5 & 12,5 \\
\hline PP2 & & II & 10 & 15 \\
\hline PP3 & & $\mathrm{I}$ & 12,5 & 17,5 \\
\hline PP4 & \multirow{3}{*}{ Provinsi } & III & 15 & 20 \\
\hline PP5 & & II & 17,5 & 22,5 \\
\hline PP6 & & $\mathrm{I}$ & 20 & 25 \\
\hline PP7 & \multirow{3}{*}{ Nasional } & III & 22,5 & 27,5 \\
\hline PP8 & & II & 25 & 30 \\
\hline PP9 & & I & 27,5 & 32,5 \\
\hline PP0 & Tidak ada & Tidak ada & 0 & 0 \\
\hline
\end{tabular}


4. Hasil dan Pembahasan

Terdapat 10 orang siswa sebagai kandidat yang akan dicari peringkat prioritas/peluang untuk perekrutan calon penerima beasiswa Gerbang Mentaya seperti yang ditulis pada Tabel 5, yang diperoleh dari hasil pengecekkan kelengkapan persyaratan berkas pendaftaran dari para kandidat.

Tabel 5. Hasil Pengecekan Kelengkapan Persyaratan Beasiswa

\begin{tabular}{llllllll}
\hline \multirow{2}{*}{ NPM } & \multirow{2}{*}{ Nama Mahasiswa } & \multicolumn{7}{l}{ Hasil Pengecekan } \\
\cline { 3 - 7 } & & P1 & P2 & P3 & P4 & P5 & P6 \\
\hline 1257201001395 & Erwinda Sri Ramadhani & Y & T & L & Y & PP1B & B \\
\hline 1357201001463 & Gt. Idris Said & T & Y & L & Y & PP0 & TB \\
\hline 1357201001587 & Hanura Djoyo Diarjo & Y & T & L & Y & PP4B & B \\
\hline 1457201001646 & Nur Jennah & T & Y & L & Y & PP4P & B \\
\hline 1457201001663 & Puput Nada Muslika & Y & Y & L & Y & PP0 & B \\
\hline 1557201001739 & Bayu Nur Rohman & Y & T & L & Y & PP0 & B \\
\hline 1557201001741 & Benny Setyawan & Y & Y & L & Y & PP3B & B \\
\hline 1557201001743 & Teddyanur & Y & Y & L & Y & PP3P & B \\
\hline 1557201001746 & Ronny Effendi & Y & T & L & Y & PP0 & B \\
\hline 1557201001747 & Aulia Ulfah & Y & Y & L & Y & PP0 & B \\
\hline Keterangan: Y $=$ Ya, T = Tidak, L = Lengkap, B = Benar, dan TB = Tidak & \\
Benar & & & & & \\
\hline
\end{tabular}

Alur penyelesaian permasalahan pada penelitian ini terbagi menjadi dua tahap, yaitu a) Sub 4.1 menjelaskan pemakaian metode AHP untuk menganalisis kelayakan perbandingan nilai antar kriteria sampai mendapatkan nilai Prioritas untuk setiap kriteria, dan b) Sub 4.2 menjelaskan pemakaian metode Profile Matching untuk mencari nilai setiap kandidat sebagai solusi perekrutan penerima beasiswa ini.

4.1 Analisis Nilai CR dan Mencari Nilai Prioritas Kriteria-kriteria dengan Metode AHP

Langkah-langkah untuk menganalisis nilai CR adalah sebagai berikut:

a. Menyusun Matriks Perbandingan Berpasangan

Kriteria-kriteria untuk permasalahan beasiswa ini dapat diadakan perbandingan tingkat kepentingannya seperti nilai-nilai bilangan bulat yang tertulis pada Tabel 6 .

Tabel 6. Matriks Perbandingan Berpasangan

\begin{tabular}{lllllll}
\hline Kriteria & P1 & P2 & P3 & P4 & P5 & P6 \\
\hline P1 & 1 & 9 & 3 & 9 & 9 & 5 \\
\hline P2 & 0,111111 & 1 & 5 & 7 & 7 & 5 \\
\hline P3 & 0,333333 & 0,2 & 1 & 3 & 3 & 3 \\
\hline P4 & 0,111111 & 0,1428571 & 0,333333 & 1 & 7 & 7 \\
\hline P5 & 0,111111 & 0,1428571 & 0,333333 & 0,142857 & 1 & 7 \\
\hline P6 & 0,2 & 0,2 & 0,333333 & 0,142857 & 0,142857 & 1 \\
\hline Jumlah & 1,866667 & 10,685714 & 10 & 20,28571 & 27,14286 & 28 \\
\hline
\end{tabular}


b. Menyusun Matriks Nilai Kriteria

Matriks Nilai Kriteria di Tabel 7 dihasilkan dari Matriks Perbandingan Berpasangan (Tabel 6) yaitu dengan cara nilai untuk setiap baris kriteria dibagi dengan nilai Jumlah untuk setiap kolom kriteria. Kolom Jumlah pada Tabel 7 merupakan akumulasi nilai untuk setiap kolom kriteria, yang kemudian dibagi dengan jumlah (macam) kriteria permasalahan untuk mendapatkan nilai Prioritas pada Tabel 7.

Tabel 7. Matriks Nilai Kriteria

\begin{tabular}{llllll}
\hline Kriteria & P1 & P2 & P3 & P4 \\
\cline { 1 - 5 } P1 & 0,535714 & 0,842246 & 0,3 & 0,443662 \\
\cline { 1 - 5 } P2 & 0,059524 & 0,0935829 & 0,5 & 0,34507 & \\
\cline { 1 - 5 } P3 & 0,178571 & 0,0187166 & 0,1 & 0,147887 & \\
\hline P4 & 0,059524 & 0,013369 & 0,033333 & 0,049296 & \\
\hline P5 & 0,059524 & 0,013369 & 0,033333 & 0,007042 & \\
\hline P6 & 0,107143 & 0,0187166 & 0,033333 & 0,007042 & \\
\hline Kriteria & P5 & P6 & Jumlah & Prioritas & Urutan \\
\hline P1 & 0,331579 & 0,178571 & 2,631773 & 0,438629 & 1 \\
\hline P2 & 0,257895 & 0,178571 & 1,434643 & 0,239107 & 2 \\
\hline P3 & 0,110526 & 0,107143 & 0,662845 & 0,110474 & 4 \\
\hline P4 & 0,257895 & 0,25 & 0,663417 & 0,110569 & 3 \\
\hline P5 & 0,036842 & 0,25 & 0,40011 & 0,066685 & 5 \\
\hline P6 & 0,005263 & 0,035714 & 0,207212 & 0,034535 & 6 \\
\hline
\end{tabular}

c. Menyusun Matriks Penjumlahan Per Baris

Matriks Penjumlahan Per Baris pada Tabel 8 dapat dibuat dengan operasi perkalian antara data Matriks Perbandingan Berpasangan (Tabel 6) dan nilai Prioritas (Tabel 7). Data dari baris Jumlah di Tabel 6 tidak disertakan dalam operasi perkalian ini.

Tabel 8. Matriks Penjumlahan Per Baris

\begin{tabular}{lllllll}
\hline P1 & P2 & P3 & P4 & P5 & P6 & Jumlah Per Baris \\
\hline 0,43862877 & 2,151965 & 0,3314223 & 0,995125 & 0,600166 & 0,172677 & 4,68998369 \\
\hline 0,04873653 & 0,239107 & 0,5523704 & 0,773986 & 0,466796 & 0,172677 & 2,253672862 \\
\hline 0,14620959 & 0,047821 & 0,1104741 & 0,331708 & 0,200055 & 0,103606 & 0,939874911 \\
\hline 0,04873653 & 0,034158 & 0,0368247 & 0,110569 & 0,466796 & 0,241748 & 0,93883228 \\
\hline 0,04873653 & 0,034158 & 0,0368247 & 0,015796 & 0,066685 & 0,241748 & 0,443947989 \\
\hline 0,087725754 & 0,047821 & 0,0368247 & 0,015796 & 0,009526 & 0,034535 & 0,232229377 \\
\hline
\end{tabular}

d. Menyusun Bahan Hitungan CR

Bahan hitungan untuk mencari nilai CR menggunakan data Jumlah Per Baris (Tabel 8) dan data nilai Prioritas (Tabel 7). Bahan hitungan untuk langkah ini disusun pada Tabel 9. 
Tabel 9. Bahan Hitungan Consistency Ratio

\begin{tabular}{llll}
\hline Kriteria & Jumlah Per Baris & Prioritas & Hasil \\
\hline P1 & 4,68998369 & 0,438629 & 5,128612 \\
\hline P2 & 2,253672862 & 0,239107 & 2,49278 \\
\hline P3 & 0,939874911 & 0,110474 & 1,050349 \\
\hline P4 & 0,93883228 & 0,110569 & 1,049402 \\
\hline P5 & 0,443947989 & 0,066685 & 0,510633 \\
\hline P6 & 0,232229377 & 0,034535 & 0,266765 \\
\hline Jumlah & & & 10,49854 \\
\hline
\end{tabular}

e. Menghitung Kelayakan Perbandingan Antar Kriteria

Dalam permasalahan beasiswa ini terdapat 6 macam persyaratan/kriteria, maka nilai variabel $\mathrm{n}$ (Ukuran Matrik) adalah 6, sehingga nilai Index Random (IR) mengacu pada baris ke-6 pada Skala Nilai Random Indeks (Tabel 2), yaitu sebesar 1.24. Langkah-langkah untuk mendapatkan nilai Consistency Ratio (CR) dimulai dengan mencari nilai $\lambda$ maks dan Consistency Index (CI) dengan perincian sebagai berikut:

$$
\begin{aligned}
& \lambda \text { maks }=\text { Hasil } / \mathrm{n}=10,49854 / 6=1.749757 . \\
& \mathrm{CI}=(\lambda \text { maks }-\mathrm{n}) / \mathrm{n}=(1.749757-6) / 6=-0.70837 . \\
& \mathrm{CR}=\mathrm{CI} / \mathrm{IR}=-0.70837 / 1.24=-0.57127 .
\end{aligned}
$$

Karena CR memiliki nilai lebih kecil dari 0.1, maka tatanan nilai-nilai perbandingan tiap-tiap derajat kepentingan di Matriks Perbandingan Berpasangan dapat diterima, sehingga tahap pencarian solusi dapat dilakukan.

\subsection{Pencarian solusi dengan Metode PM}

Pencarian solusi dengan metode PM terdiri dari langkah-langkah berikut:

a. Menyusun Penilaian terhadap Data Hasil Pengecekan Kelengkapan Persyaratan Beasiswa

Pada langkah ini dibuat penilaian terhadap Hasil Pengecekan Kelengkapan Persyaratan Beasiswa (Tabel 5), dan hasil penilaian ini ditulis pada Tabel 10 .

Tabel 10. Penilaian Terhadap Data Hasil Pengecekan Kelengkapan Persyaratan Beasiswa

\begin{tabular}{lrrrrrr}
\hline \multirow{2}{*}{ NPM } & \multicolumn{7}{c}{ Nilai untuk Setiap Kriteria } \\
\cline { 2 - 8 } & P1 & P2 & P3 & P4 & P5 & P6 \\
\hline 1257201001395 & 4 & 0 & 4 & 4 & 2 & 4 \\
\hline 1357201001463 & 0 & 4 & 4 & 4 & 1 & 0 \\
\hline 1357201001587 & 4 & 0 & 4 & 4 & 3 & 4 \\
\hline 1457201001646 & 0 & 4 & 4 & 4 & 3 & 4 \\
\hline
\end{tabular}


Tabel 10. (Lanjutan)

\begin{tabular}{lrrrrrr}
\hline \multirow{2}{*}{ NPM } & \multicolumn{7}{l}{ Nilai untuk Setiap Kriteria } \\
\cline { 2 - 7 } & P1 & P2 & P3 & P4 & P5 & P6 \\
\hline 1457201001663 & 4 & 4 & 4 & 4 & 1 & 4 \\
\hline 1557201001739 & 4 & 0 & 4 & 4 & 1 & 4 \\
\hline 1557201001741 & 4 & 4 & 4 & 4 & 3 & 4 \\
\hline 1557201001743 & 4 & 4 & 4 & 4 & 3 & 4 \\
\hline 1557201001746 & 4 & 0 & 4 & 4 & 1 & 4 \\
\hline 1557201001747 & 4 & 4 & 4 & 4 & 1 & 4 \\
\hline
\end{tabular}

b. Mencari nilai Selisih/Gap untuk Setiap Kriteria

Data Selisih Gap (Tabel 11) disusun dari data pada Tabel 10 kemudian dikurangkan dengan nilai-nilai pengurang untuk tiap-tiap kriteria.

Tabel 11. Selisih/Gap untuk Setiap Kriteria

\begin{tabular}{|c|c|c|c|c|c|c|}
\hline \multirow{2}{*}{ NPM } & \multicolumn{6}{|c|}{ Nilai untuk Setiap Kriteria } \\
\hline & $\mathrm{P} 1$ & $\mathrm{P} 2$ & P3 & $\mathrm{P} 4$ & P5 & P6 \\
\hline 1257201001395 & 4 & 0 & 4 & 4 & 2 & 4 \\
\hline 1357201001463 & 0 & 4 & 4 & 4 & 1 & 0 \\
\hline 1357201001587 & 4 & 0 & 4 & 4 & 3 & 4 \\
\hline 1457201001646 & 0 & 4 & 4 & 4 & 3 & 4 \\
\hline 1457201001663 & 4 & 4 & 4 & 4 & 1 & 4 \\
\hline 1557201001739 & 4 & 0 & 4 & 4 & 1 & 4 \\
\hline 1557201001741 & 4 & 4 & 4 & 4 & 3 & 4 \\
\hline 1557201001743 & 4 & 4 & 4 & 4 & 3 & 4 \\
\hline 1557201001746 & 4 & 0 & 4 & 4 & 1 & 4 \\
\hline 1557201001747 & 4 & 4 & 4 & 4 & 1 & 4 \\
\hline Pengurang & 4 & 4 & 4 & 4 & 5 & 4 \\
\hline \multirow{2}{*}{ NPM } & \multicolumn{6}{|c|}{ Hasil Selisih/Gap untuk Setiap Kriteria } \\
\hline & $\mathrm{P} 1$ & $\mathrm{P} 2$ & P3 & $\mathrm{P} 4$ & P5 & P6 \\
\hline 1257201001395 & 0 & -4 & 0 & 0 & -3 & 0 \\
\hline 1357201001463 & -4 & 0 & 0 & 0 & -4 & -4 \\
\hline 1357201001587 & 0 & -4 & 0 & 0 & -2 & 0 \\
\hline 1457201001646 & -4 & 0 & 0 & 0 & -2 & 0 \\
\hline 1457201001663 & 0 & 0 & 0 & 0 & -4 & 0 \\
\hline 1557201001739 & 0 & -4 & 0 & 0 & -4 & 0 \\
\hline 1557201001741 & 0 & 0 & 0 & 0 & -2 & 0 \\
\hline 1557201001743 & 0 & 0 & 0 & 0 & -2 & 0 \\
\hline 1557201001746 & 0 & -4 & 0 & 0 & -4 & 0 \\
\hline 1557201001747 & 0 & 0 & 0 & 0 & -4 & 0 \\
\hline
\end{tabular}

c. Memberi Bobot Nilai untuk Tiap-tiap Selisih/Gap

Hasil dari langkah b kemudian diberi bobot nilai berdasarkan data Bobot Nilai Gap (Gambar 2). Pemberian bobot nilai untuk tiap-tiap selisih/gap para kandidat ini ditulis pada Tabel 12. 
Tabel 12. Bobot Nilai Gap untuk Setiap Kriteria

\begin{tabular}{lrrrrrr}
\hline \multirow{2}{*}{ NPM } & \multicolumn{6}{c}{ Bobot Nilai untuk Selisih/Gap untuk Tiap Kriteria } \\
\cline { 2 - 7 } & P1 & P2 & P3 & P4 & P5 & P6 \\
\hline 1257201001395 & 5 & 1 & 5 & 5 & 2 & 5 \\
\hline 1357201001463 & 1 & 5 & 5 & 5 & 1 & 1 \\
\hline 1357201001587 & 5 & 1 & 5 & 5 & 3 & 5 \\
\hline 1457201001646 & 1 & 5 & 5 & 5 & 3 & 5 \\
\hline 1457201001663 & 5 & 5 & 5 & 5 & 1 & 5 \\
\hline 1557201001739 & 5 & 1 & 5 & 5 & 1 & 5 \\
\hline 1557201001741 & 5 & 5 & 5 & 5 & 3 & 5 \\
\hline 1557201001743 & 5 & 5 & 5 & 5 & 3 & 5 \\
\hline 1557201001746 & 5 & 1 & 5 & 5 & 1 & 5 \\
\hline 1557201001747 & 5 & 5 & 5 & 5 & 1 & 5 \\
\hline
\end{tabular}

\section{d. Mencari Nilai CF dan Nilai SF}

Dengan melihat urutan descending nilai Prioritas tiap-tiap kriteria di Matriks Nilai Kriteria (Tabel 7), maka kelompok CF meliputi kriteria P1, P2, dan P4, sedangkan kelompok SF meliputi kriteria P3, P5, dan P6. Dengan bobot nilai yang diperoleh dari langkah $b$ dapat dicari ratarata nilai $\mathrm{CF}$ dan rata-rata nilai $\mathrm{SF}$ di Tabel 13.

Tabel 13. Nilai CF dan Nilai SF para Kandidat

\begin{tabular}{lll}
\hline \multirow{2}{*}{ NPM } & Rata2 CF & Rata2 SF \\
\cline { 2 - 3 } & $(\mathrm{P} 1+\mathrm{P} 2+\mathrm{P} 4) / 3$ & $(\mathrm{P} 3+\mathrm{P} 5+\mathrm{P} 6) / 3$ \\
\hline 1257201001395 & 3,666666667 & 4 \\
\hline 1357201001463 & 3,666666667 & 2,333333333 \\
\hline 1357201001587 & 3,666666667 & 4,333333333 \\
\hline 1457201001646 & 3,666666667 & 4,333333333 \\
\hline 1457201001663 & 5 & 3,666666667 \\
\hline 1557201001739 & 3,666666667 & 3,666666667 \\
\hline 1557201001741 & 5 & 4,333333333 \\
\hline 1557201001743 & 5 & 4,333333333 \\
\hline 1557201001746 & 3,666666667 & 3,666666667 \\
\hline 1557201001747 & 5 & 3,666666667 \\
\hline
\end{tabular}

e. Mencari Nilai untuk Tiap-tiap Kandidat

Karena CF dan SF terdiri dari lebih dari satu kriteria, maka bobot CF dan bobot SF dihitung dari rata-rata Prioritas dari masing-masing kriteria yang telah ditulis pada Matriks Nilai Kriteria dari metode AHP (Tabel 7). Bobot $\mathrm{CF}$ dan bobot SF dapat dihitung dengan perincian di bawah ini.

$$
\begin{aligned}
& \text { Bobot CF }=(0,438629+0,239107+0,110569) / 3=0.262768475 . \\
& \text { Bobot SF }=(0,110474+0,066685+0,034535) / 3=0.070564859 .
\end{aligned}
$$


Hasil penilaian untuk setiap kandidat yang ditulis pada Tabel 14 dapat dihitung dengan rumus pada Persamaan 7:

Nilai responden $(\mathrm{i})=$ Rata-rata $\mathrm{CF}(\mathrm{i}) *$ Bobot $\mathrm{CF}+$

$$
\text { Rata-rata } \mathrm{SF}(\mathrm{i}) * \text { Bobot SF. }
$$

Tabel 14 memuat informasi keputusan sementara perekrutan dari sisi hasil penilaian tiap-tiap kandidat.

Tabel 14. Keputusan Sementara Berdasarkan Penilaian

\begin{tabular}{lll}
\hline NPM & Nilai & Keputusan Sementara \\
\hline 1257201001395 & 1,245743842 & Tidak diusulkan \\
\hline 1357201001463 & 1,128135744 & Tidak diusulkan \\
\hline 1357201001587 & 1,269265461 & Tidak diusulkan \\
\hline 1457201001646 & 1,269265461 & Tidak diusulkan \\
\hline 1457201001663 & 1,572580189 & Diusulkan \\
\hline 1557201001739 & 1,22222222 & Tidak diusulkan \\
\hline 1557201001741 & 1,619623428 & Diusulkan \\
\hline 1557201001743 & 1,619623428 & Diusulkan \\
\hline 1557201001746 & 1,22222222 & Tidak diusulkan \\
\hline 1557201001747 & 1,572580189 & Diusulkan \\
\hline
\end{tabular}

Dengan data Nilai di Tabel 14 dapat diperoleh rata-rata nilai sebesar 1,374126 sebagai nilai minimal yang dapat diusulkan menerima beasiswa, dari sisi hasil penilaian.

Berdasarkan status warga tetap kabupaten dan status tidak sedang memerima beasiswa dari pihak lain sebagai kriteria permasalahan (Tabel 3 ), terdapat dua buah keputusan sementara untuk tiap-tiap kandidat seperti yang ditulis pada Tabel 15 .

Tabel 15. Keputusan Sementara Berdasarkan Status Kependudukan dan Tidak Menerima Beasiswa Dari Pihak Lain

\begin{tabular}{lll}
\hline \multirow{2}{*}{ NPM } & \multicolumn{2}{l}{ Keputusan Sementara } \\
\cline { 2 - 3 } & Status Penduduk & Tidak Menerima Beasiswa dari Pihak Lain \\
\hline 1257201001395 & Diusulkan & Diusulkan \\
\hline 1257201001395 & Diusulkan & Diusulkan \\
\hline 1357201001463 & Tidak diusulkan & Tidak diusulkan \\
\hline 1357201001587 & Diusulkan & Diusulkan \\
\hline 1457201001646 & Tidak diusulkan & Diusulkan \\
\hline 1457201001663 & Diusulkan & Diusulkan \\
\hline 1557201001739 & Diusulkan & Diusulkan \\
\hline 1557201001741 & Diusulkan & Diusulkan \\
\hline 1557201001743 & Diusulkan & Diusulkan \\
\hline 1557201001746 & Diusulkan & Diusulkan \\
\hline 1557201001747 & Diusulkan & Diusulkan \\
\hline
\end{tabular}

f. 


\section{g. Solusi Akhir}

Berdasarkan data keputusan sementara di Tabel 14 dan Tabel 15, maka solusi akhir dapat diperoleh dengan melibatkan operasi logika AND untuk dapat menemukan para kandidat yang benar-benar layak diusulkan menerima Beasiswa Gerbang Mentaya. Solusi akhir dari permasalahan beasiswa ini dapat diperinci pada Tabel 16.

Tabel 16. Solusi Akhir

\begin{tabular}{llll}
\hline \multirow{2}{*}{ NIM } & \multicolumn{3}{l}{ Penilaian untuk Keputusan Sementara } \\
\cline { 2 - 4 } & Nilai & Status Warga & Tidak Menerima Beasiswa dari Pihak Lain \\
\hline 1257201001395 & 0 & 1 & 1 \\
\hline 1357201001463 & 0 & 0 & 0 \\
\hline 1357201001587 & 0 & 1 & 1 \\
\hline 1457201001646 & 0 & 0 & 1 \\
\hline 1457201001663 & 1 & 1 & 1 \\
\hline 1557201001739 & 0 & 1 & 1 \\
\hline 1557201001741 & 1 & 1 & 1 \\
\hline 1557201001743 & 1 & 1 & 1 \\
\hline 1557201001746 & 0 & 1 & 1 \\
\hline 1557201001747 & 1 & 1 & 1 \\
\hline NIM & Solusi Akhir & Arti Solusi \\
\hline 1257201001395 & 0 & & Tidak diusulkan \\
\hline 1357201001463 & 0 & & Tidak diusulkan \\
\hline 1357201001587 & 0 & & Tidak diusulkan \\
\hline 1457201001646 & 0 & & Tidak diusulkan \\
\hline 1457201001663 & 1 & & Diusulkan \\
\hline 1557201001739 & 0 & Tidak diusulkan \\
\hline 1557201001741 & 1 & Diusulkan \\
\hline 1557201001743 & 1 & Diusulkan \\
\hline 1557201001746 & 0 & Tidak diusulkan \\
\hline 1557201001747 & 1 & & Diusulkan \\
\hline
\end{tabular}

Jadi, diperoleh empat mahasiswa yang layak diusulkan menerima Beasiswa Gerbang Mentaya, yaitu dengan NIM 1457201001663 (Puput Nada Muslika), 1557201001741 (Benny Setyawan), 1557201001743 (Teddyanur), dan 1557201001747 (Aulia Ulfah).

5. Kesimpulan

Kesimpulan yang dapat dibuat oleh peneliti setelah selesai melakukan analisis pada kasus perekrutan calon penerima Beasiswa Gerbang Mentaya ini adalah:

a. Metode AHP dan metode PM dapat digabungkan untuk menyelesaikan permasalahan pada penelitian ini, yaitu metode AHP dipakai pada tahap analisis terhadap kelayakan perbandingan nilai-nilai derajat kepentingan setiap kriteria sebelum tahap pencarian solusi dapat dilakukan. Jika analisis ini dapat diterima, berarti tatanan nilai-nilai perbandingan derajat kepentingan setiap kriteria sudah bagus, hal ini ditandai dengan nilai CR harus lebih kecil dari 0.1. Metode AHP juga dapat dipakai untuk mencari 
nilai Prioritas tiap-tiap kriteria pada Matriks Nilai Kriteria AHP, yang kemudian dipakai oleh metode PM sebagai acuan untuk mengelompokkan kriteria-kriteria ke dalam kelompok CF dan keompok SF. Tak kalah penting untuk diperhatikan adalah pemberian Beasiswa Gerbang Mentaya ini memang khusus diberikan kepada para calon penerima yang benarbenar menjadi penduduk tetap kabupaten yang tidak sedang menerima beasiswa dari pihak lain. Untuk itu pada langkah akhir tahap pencarian solusi dapat ditambahkan sebuah langkah untuk mengeliminasi para kandidat yang tidak memenuhi dua persyaratan ini, dan hal ini dapat dikerjakan dengan suatu operasi logika untuk mengolah hasil penilaian para kandidat, status kependudukan para kandidat, dan status tidak sedang menerima beasiswa dari pihak lain.

b. Tingkat akurasi perhitungan melalui keluaran program maupun melalui pemberian formula Microsoft Excel sama-sama memberi hasil akurat, dan berbeda dengan keluaran yang didapat dengan perhitungan di atas kertas yang memiliki kesempatan salah tulis ketika menyalin ulang hasil perhitungan dari kalkulator.

6. Daftar Pustaka

[1] Jogianto, H.M., 1993, Analisis dan Desain Sistem Informasi: Pendekatan Terstruktur, Teori dan Praktek Aplikasi Bisnis, Edisi I, Andi Offset, Yogyakarta.

[2] Turban, Efraim; Aronson, Jay E.; Liang, Ting-Peng, 2005, Decision Support Systems and Intelligent Systems-7th Ed Jilid 1, Andi Offset, Yogyakarta.

[3] Wahid, Fathul, 2005, Kamus Istilah Teknologi Informasi, Andi Offset, Yogyakarta.

[4] Sasongko, Aji; Astuti, Indah Fitri; Maharani, Septya, 2017, Pemilihan Karyawan Baru dengan Metode AHP (Analytic Hierarchy Process), Jurnal Informatika Mulawarman, Vol. 12, No. 2 September 2017.

[5] Kusrini, 2007, Konsep dan Sistem Pendukung Keputusan, Andi Offset, Yogyakarta.

[6] Astradanta, Made; Wirawan, I Made Agus; Arthana, I Ketut Resika, 2016, Pengembangan Sistem Penunjang Keputusan Pemilihan Tempat Kuliner Dengan Menggunakan Metode AHP Dan SAW Studi Kasus : Kecamatan Buleleng, Jurusan Pendidikan Teknik Informatika, Universitas Pendidikan Ganesha.

[7] Puspitasari, T.D; Sari, E.O; Destarianto, P; H Y Riskiawan, H.Y, 2017, Decision Support System for Determining Scholarship Selection using an Analytical Hierarchy Process, International Joint Conference on Science and Technology (IJCST), IOP Conf. Series: Journal of Physics: Conf. Series 953 (2018) 012119, doi :10.1088/1742-6596/953/1/012119.

[8] Sambani, Egi Badar; Mulyana, Dadang; Maulana, Irfan, 2016, Sistem Pendukung Keputusan Kelayakan Penerimaan Pengajar Menggunakan 
Metode Profile Matching (Studi Kasus pada ELTI Gramedia Tasikmalaya), Journal of Applied Intelligent System, Vol. 1, No. 2, Juni 2016.

[9] Khotijah, Siti; Marlina, Dwi; Driyani, Dewi, 2017, Pemilihan Taman Kanak-kanak di Wilayah Jagakarsa dengan Profile Matching, IkraithInformatika, Vol. 1, No. 2, November 2017.

[10] Moedjiono; Kurnianda, Nia Rahma; Kusdaryono, Aries, 2016, Decision Support Model for User Submission Approval Energy Partners Candidate Using Profile Matching Method and Analytical Hierarchy Process, Scientific Journal of Informatics, Vol. 3, No. 2, November 2016.

[11] Sahureka, Abraham Obeth Petrus, 2017, Decision Support System in the Placement of Electronic Officer of Indonesian Navy with Profile Matching Method, International Journal of Engineering Research \& Technology (IJERT), Vol. 6 Issue 01.

[12] Elmayati, 2016, Aplikasi Sistem Informasi Pengajuan Beasiswa Berbasis Web pada Sekolah Tinggi Manajemen dan Ilmu Komputer Musi Rawas (STMIK-MURA) Kota Lubuklinggau, JUSIM, Vol 1 No.1, Desember 2016.

[13] Nugroho, Deni Kurnianto, 2018, Pengembangan dan Analisis Kualitas Sistem Pendukung Keputusan sebagai Aplikasi Rekomendasi Pemilihan Beasiswa di Perguruan Tinggi, Skripsi, Fakultas Teknik, Universitas Negeri Yogyakarta.

[14] TNP2K, 2015, Penetapan Solusi Masalah Kepesertaan dan Pemutakhiran Data Penerima KPS. Jakarta.

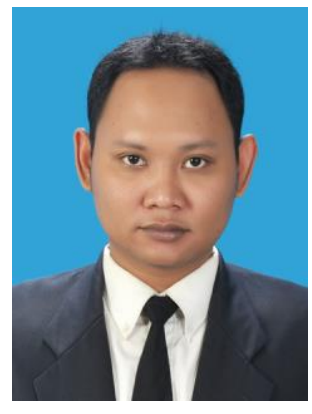

1. Nama

$:{ }^{1}$ Lukman Bachtiar, ${ }^{2}$ Kusrini

2. Judul

: Analisis Pemilihan Calon Penerima
Beasiswa Daerah dengan Metode
Analytical Hierarchy Process dan Profile
Matching

3. Deskripsi Diri

$$
\begin{aligned}
& \text { : }{ }^{1} \text { Mahasiswa Pascasarjana Teknik } \\
& \text { Informatika Universitas AMIKOM } \\
& \text { Yogyakarta. } \\
& { }^{2} \text { Dosen Pembimbing Tesis. Direktur } \\
& \text { Pascasarjana Teknik Informatika } \\
& \text { Universitas AMIKOM Yogyakarta }
\end{aligned}
$$

